Int. J. Electrochem. Sci., 13 (2018) $6072-6082$

\title{
Investigation of the corrosion behavior of phosphate coated magnesium in a Kokubo Solution.
}

\author{
H. Quintana-Camacho ${ }^{1}$, J. L. Ramírez-Reyes ${ }^{1}$, A. L. Medina-Almazán ${ }^{3}$, N. García-Navarro ${ }^{2}$, \\ G. Galicia-Aguilar ${ }^{1, *}$ \\ ${ }^{1}$ Instituto de Ingeniería, Universidad Veracruzana Av. Juan Pablo II s/n Frac. Costa Verde, Boca del \\ Río Ver., C. P. 94294, México. \\ ${ }^{2}$ Facultad de Ciencias Químicas, Universidad Veracruzana. Av. Venustiano Carranza s/n Col. \\ Revolución, Poza Rica, Ver., C. P. 93396, México. \\ ${ }^{3}$ Departamento de Tecnología de Materiales, Instituto Nacional de Investigaciones Nucleares. \\ Carretera México - Toluca s/n, La Marquesa, Ocoyoacac, Estado de México, C. P. 52750, México. \\ *E-mail: gogalicia@uv.mx
}

doi: $10.20964 / 2018.06 .53$

Received: 7 March 2018 / Accepted: 10 April 2018 / Published: 10 May 2018

\begin{abstract}
Magnesium is a biocompatible element. Nevertheless, in order for it to be used as a prosthesis or implant, it is necessary that the organism is able to assimilate it. Thus, it is essential to control its degradation rate. There are two means so as to reach this objective. The former consists in looking for one element to alloy it. As for the latter, a compound precipitation could be induced by means of a chemical conversion treatment. In the present work, we focused on the induction of $\mathrm{Mg}_{3}\left(\mathrm{PO}_{4}\right)_{2}$ precipitation on a $\mathrm{Mg}$ surface from a phosphate solution of $\mathrm{pH} 10$. The obtained compound was characterized by means of Scanning Electron Microscopy (SEM), X-Ray diffraction (XRD) and ellipsometry. Corrosion rate (CR) of $\mathrm{Mg}$ with the obtained precipitate was measured in a Kokubo solution by means of Linear Polarization Resistance (LPR); the capacitor at the metal-electrolyte interphase was determined using Electrochemical Impedance Spectroscopy (EIS) experimental data by varying the stabilization and exposition time. Results reveal the presence of $\mathrm{Mg}_{3}\left(\mathrm{PO}_{4}\right)_{2}$ and $\mathrm{Mg}\left(\mathrm{H}_{2} \mathrm{PO}_{4}\right)_{2}$ on the $\mathrm{Mg}$ surface. It is suggested that the presence of $\mathrm{MgO}$ and $\mathrm{Mg}(\mathrm{OH})_{2}$ favors the precipitation of $\mathrm{Mg}_{3}\left(\mathrm{PO}_{4}\right)_{2}$ on the surface of pure $\mathrm{Mg}$ exposed to a Kokubo solution. In the presence of $\mathrm{Mg}_{3}\left(\mathrm{PO}_{4}\right)_{2}$ precipitate, the $\mathrm{CR}$ of $\mathrm{Mg}$ in a Kokubo solution decreases in an order of magnitude.
\end{abstract}

Keywords: Magnesium, Biomaterials, Phosphate Coating.

\section{FULL TEXT}


(C) 2018 The Authors. Published by ESG (www.electrochemsci.org). This article is an open access article distributed under the terms and conditions of the Creative Commons Attribution license (http://creativecommons.org/licenses/by/4.0/). 